\title{
Capital Allocation Efficiency Evaluation of Energy Conservation and Environmental Protection Enterprises in the Yangtze River Delta of China
}

\author{
Hongjun Xiong
}

School of Business, Shanghai Dianji University, Shanghai 201306, China; jackson0306@163.com

Nat. Env. \& Poll. Tech. Website: www.neptjournal.com

Received: 20-02-2020

Accepted: 10-04-2020

Key Words:

Energy conservation; Environmental protection; Capital allocation efficiency; Yangtze river delta

\begin{abstract}
Various measures are implemented to promote the construction of China's ecology. These measures aim to accelerate the green transformation of the economy and promote the rapid development of energy conservation and environmental protection industry under the promotion of relevant policies. Consequently, the numbers of enterprises and the market scale have shown explosive growth. However, energy conservation and environmental protection enterprises are faced with lack of technological innovation, shortage of capital, and high cost. Effective measures must optimize the efficiency of capital allocation. To evaluate the capital allocation efficiency of energy conservation and environmental protection enterprises, 26 listed companies of energy conservation and environmental protection in the Yangtze River Delta of China were selected as samples. Monetary capital, accounts receivable, inventory, fixed assets, and construction in progress were used as input scalars. Net profit, undistributed profit, and surplus reserve were used as output variables. The Data Envelopment Analysis (DEA) model was used for analysis. Results show that capital allocation efficiency of 11 sample companies is DEA-effective. Power, heat, gas, water production, and supply industry rank first with the real estate industry divided by industry. Shanghai ranks first in the regional division. Specific improvement strategies are proposed for non-DEA effective sample enterprises.
\end{abstract}

\section{INTRODUCTION}

The energy conservation and environmental protection industry provide technical basis and equipment support for energy conservation, circular economic development, and environmental protection. Among the specific industries included are energy conservation, resource recycling, and environmental protection equipment, which are involved in conservation, energy-saving products and services (Wang 2017). The 13th Five-Year Plan for the development of energy conservation and environmental protection industry proposes to develop energy conservation and environmental protection industry and strengthen the prevention and control of air, water, soil, and other pollution. At the same time, by 2020, energy conservation and environmental protection industry will become a pillar of the national economy.

In 2018, China's environmental protection and energy conservation support reached 635.3 billion yuan, with a year-on-year increase of $13 \%$. The proportion of financial expenditure of the environmental protection industry in the GDP has increased as well. In the same year, the proportion of financial expenditure of the environmental protection industry in GDP was $0.7 \%$. In recent years, China's energy conservation and environmental protection industry has grown rapidly, with the total output value increasing from approximately 3 trillion yuan in 2012 to 5.8 trillion yuan in 2017 and breaking through 7 trillion yuan in 2018. This growth was driven by the acceleration of ecological civilization construction, establishment and implementation of demonstration pilot projects in multiple circular economy fields, and improvement of public awareness of energy conservation and environmental protection. With the continuous increase of policies and regulations, such as environmental protection tax and emission permit system, the market space of China's energy conservation and environmental protection industry will continue to expand in the future (Peng et al. 2017, Bravo-Macias et al. 2019). Hence, the output value of energy conservation and environmental protection industry is expected to exceed 10 trillion yuan in 2020. However, the development of energy conservation and environmental protection industry depends on the forced promotion of policies (Xiong et al. 2010, Xiong et al. 2020). Driven by the policy, the potential demand for energy conservation and environmental protection will become a huge market space, which can attract the convergence of various capitals and enterprises and stimulate new employment demand. The development of energy conservation and environmental protection to a certain scale can realize the win-win of social and economic benefits. 
From the perspective of industrial structure, the further expansion of industrial-scale can result in the large proportion for energy-saving and environmental protection equipment manufacturing industry. Furthermore, the proportion of the energy-saving and environmental protection service industry can further increase. With the acceleration of the market-oriented process, new modes and formats are rapidly emerging in the energy-saving and environmental protection industry. These trends continue the improvement of industrial scale and technology level. At the same time, the government continues to issue policies that promote enterprises to increase capital investment and subsequently form a diversified financing pattern (Sun 2018). However, problems such as unreasonable structure, irregular market, low industrial concentration, weak technological innovation ability (Yan et al. 2019), fund shortage and imperfect service system must be solved. The energy conservation and environmental protection industry is a heavy asset industry with large investment and long cycle. However, many small and medium-sized energy conservation and environmental protection enterprises in China lack financing capacity and serious capital shortage (Hao et al. 2018). According to the Development Research Center of the State Council, the corresponding investment demand for green development in China from 2015 to 2020 is approximately 2.9 trillion yuan per year. The proportion of government investment only accounts for $10 \%-15 \%$, which is more than $80 \%$ of the funds needed to be solved by social capital. Thus, the financing demand for green development is in great shortage. Therefore, the efficiency of capital allocation of the energy conservation and environmental protection industry is worth exploring. The input is capital, whereas output comprises the indicators of operating results and equity. The source of capital includes equity capital and debt capital, and assets are the external form of expression. Assets come in various kinds. Different input combinations determine different output forms and output quantities. In the Yangtze River Delta region of China, economic development is fast. Environmental protection measures are increasing daily and environmental protection industrial policies are constantly issued. Studying the capital allocation efficiency of energy-saving and environmental protection enterprises in this region is significant.

The rest of this study is arranged as follows. Section 1 presents the design of research model, construction of the data envelopment analysis (DEA) model, selection of samples and indicators, and the extraction of data. Section 2 is the empirical analysis, which focuses on the DEA analysis results from the overall, industry, and regional situations, and puts forward the improvement strategy of capital allocation efficiency for energy-saving and environmental protection enterprises. Section 3 concludes this study.

\section{METHODS}

\section{Modelling}

In 1978, Charles and Cooper established an efficiency evaluation method known as the data envelopment analysis (DEA). DEA is a quantitative analysis method that aims to evaluate the effectiveness of comparable similar evaluation objects by using a linear programming method using multiple inputs and output indicators. The first DEA model proposed by Charles, Cooper, and Rhodes is the C2R model, which analyses and evaluates the effectiveness of decision-making units. The second DEA model is called the $\mathrm{BC} 2$ model, which was proposed by Banker, Charles, and Cooper in 1984. As an extension of the $\mathrm{C} 2 \mathrm{R}$ model, the $\mathrm{BC} 2$ model measures the comprehensive efficiency of multiple inputs and output decision-making units under the assumption of variable returns to scale and distinguishes comprehensive efficiency into pure technical and scale efficiency. When choosing the $\mathrm{BC} 2$ model for efficiency evaluation, an input- or output-oriented model can be used (Yu et al. 2016). This study fully considers the limited input of energy-saving and environmental protection enterprise resources and tests the output of energy-saving and environmental protection enterprises under a given capital input. Hence, the output-oriented BC2 model is selected.

The basic principle of $\mathrm{BC}^{2}$ model is that if given $n$ DMUs, each $D M U_{j}(j=1,2 \ldots n)$ uses $p$ inputs, namely $X_{i j}(i=1,2$ $\ldots p)$, and produces $q$ outputs, namely $Y_{k j}(k=1,2 \ldots q)$. The relative efficiency value of $m$ DMUs can be obtained from the following models:

$$
\left\{\begin{array}{l}
\operatorname{Max} h_{m}=\frac{\sum_{k=1}^{q} u_{k} Y_{k m}-U_{0}}{\sum_{i=1}^{p} v_{i} X_{i m}} \\
\text { s.t. } \frac{\sum_{k=1}^{q} u_{k} Y_{k j}}{\sum_{i=1}^{p} v_{i} X_{i j}} \leq 1, j=1,2, \ldots, n
\end{array}\right.
$$

In formula (1), $u_{k}$ and $v_{i}$ are weight coefficients for measuring output input, with the relation $u_{k}, v_{i} \geq \varepsilon \geq 0$. Generally, the larger $h_{m}$ is, the more output can be obtained when the input of the $m$ decision unit is certain. Therefore, the maximum value of $h_{m}$ can be examined by trying to change as many weight coefficients as possible, which can lead to judging whether the $m^{\text {th }}$ decision-making unit is relatively optimal in the decision-making unit. According to the linear programming technique, we can obtain the optimal solution $h_{m}{ }^{*}$ of the equation. If the optimal solution $h_{m}{ }^{*}=1$, then the decision unit $D M U_{m}$ is DEA-efficient. 


\section{Variables}

According to the component stocks of "beautiful China," we reduced the sample range and considered the following factors when screening. The first is selecting the samples from the Yangtze River Delta of China, which included listed companies in Zhejiang, Jiangsu, and Anhui Provinces, and Shanghai. The second is considering that the number of samples is equal to or exceeds the total number of input and output indicators twice, according to the requirements of the DEA model for samples and indicators. In this study, 26 listed companies of artificial intelligence in China are selected as samples, that is, the decision unit (DMU) in the model.

Referring to the research on capital input and output of the home appliance industry (Xu et al. 2017), we considered the characteristics of energy conservation and environmental protection industry. Thus, we selected monetary fund $\left(\mathrm{X}_{1}\right)$, account receivable $\left(\mathrm{X}_{2}\right)$, inventory $\left(\mathrm{X}_{3}\right)$, fixed assets $\left(\mathrm{X}_{4}\right)$, and construction in progress $\left(\mathrm{X}_{5}\right)$ as capital input variables of energy conservation and environmental protection enterprises. We selected net profit $\left(\mathrm{Y}_{1}\right)$, undistributed profit $\left(\mathrm{Y}_{2}\right)$, and surplus reserve $\left(\mathrm{Y}_{3}\right)$ as capital output variable of energy conservation and environmental protection enterprises, as shown in Table 1 below:

\section{Data Source}

Variable data comes from the Wind Database. Monetary capital, accounts receivable, inventory, fixed assets, and construction in progress are presented from the opening and closing balance of corresponding subjects of sample balance sheets in 2017 and 2018. Net profit, undistributed profit, and surplus reserve come from the opening and closing balance of corresponding subjects of sample balance sheets in 2017 and 2018. Table 2 presents variable data after calculation. We adjusted the variable from the negative value to 0 in the empirical analysis.

\section{RESULTS}

\section{Capital Allocation Efficiency Analysis}

The original data of input and output variables of 26 skilled environmental protection enterprises in the Yangtze River Delta of China were imported into the DEAP2.1 software, and the parameters of the guidance file were set. The decision-making unit was 26 , time was 1 year, the number of output indicators was 3 , the number of input indicators was 5 , and output leading type was $1=$ OUTPUT ORIENTATED, $1=$ VRS, 0 = DEA (MULTI-STAGE).

\section{Overall Results}

Based on the $\mathrm{BC}^{2}$ model, the operation results of the DEA of business efficiency of enterprises in the Yangtze River Delta are shown in Table 3. The average comprehensive efficiency of capital allocation and the pure technical and scale efficiency of 26 energy-saving and environmental protection enterprises in the Yangtze River Delta are 0.709, 0.739 , and 0.95 , respectively. At the same time, the results showed that the DEA of 11 sample enterprises is effective, having accounted for $42.308 \%$.

In comprehensive efficiency, 11 enterprises, such as Weifu Group, Cec Environmental Protection, and Weiming Environmental Protection, are DEA-effective, with a value of 1. Comprehensive efficiency of *St Feida is only 0.096, and the comprehensive efficiency of 11 sample enterprises is lower than the average level, indicating that the capital allocation efficiency of energy-saving and environmental protection enterprises in the Yangtze River Delta is different.

In pure technical efficiency, 11 sample enterprises are below the average level, with a minimum value of 0.097 (*ST Feida). However, although Jiaao's environmental protection has reached 1 , its scale efficiency is insufficient, resulting in a comprehensive efficiency of less than 1 .

Table 1: Capital input and output variables of energy conservation and environmental protection enterprises.

\begin{tabular}{|lll|}
\hline Variable type & Variable name & Computing method \\
\hline & Monetary fund $\left(\mathrm{X}_{1}\right)$ & \\
Input variables & Account receivable $\left(\mathrm{X}_{2}\right)$ \\
& Inventory $\left(\mathrm{X}_{3}\right)$ \\
& Fixed assets $\left(\mathrm{X}_{4}\right)$ \\
& Construction in progress $\left(\mathrm{X}_{5}\right)$ & (Initial balance + Ending balance) / 2 \\
Output variables & Net profit $\left(\mathrm{Y}_{1}\right)$ \\
& Undistributed profit $\left(\mathrm{Y}_{2}\right)$ \\
& Surplus reserves $\left(\mathrm{Y}_{3}\right)$ \\
\hline
\end{tabular}


In scale efficiency, only six sample enterprises are below the average level, with a minimum value of 0.639 (Anhui Construction Engineering Group). The scale efficiencies of Skyray Instrument, Chuangyuan Technology, and Guozhen Environmental Protection Technology are $0.999,0.997$, and 0.994 , respectively, which are close to 1 . The pure technical efficiency indicates that comprehensive efficiency is not high.

Table 2: Original data of capital input and output of energy conservation and environmental protection enterprises in the Yangtze River Delta of China (Unit: 100 Million Yuan).

\begin{tabular}{|c|c|c|c|c|c|c|c|c|c|c|}
\hline \multirow{2}{*}{$\begin{array}{l}\text { Serial } \\
\text { number }\end{array}$} & \multirow{2}{*}{ Code } & \multirow{2}{*}{ Securities abbreviation } & \multicolumn{5}{|c|}{ Input variables } & \multicolumn{3}{|c|}{ Output variables } \\
\hline & & & $\mathrm{X}_{1}$ & $\mathrm{X}_{2}$ & $\mathrm{X}_{3}$ & $\mathrm{X}_{4}$ & $\mathrm{X}_{5}$ & $\mathrm{Y}_{1}$ & $\mathrm{Y}_{2}$ & $\mathrm{Y}_{3}$ \\
\hline DMU1 & 000551 & Chuangyuan Technology & 8.364 & 5.410 & 9.534 & 8.249 & 0.968 & 1.455 & 5.828 & 1.514 \\
\hline DMU2 & 000581 & Weifu Group & 28.675 & 19.577 & 14.385 & 26.461 & 1.334 & 25.568 & 104.043 & 5.101 \\
\hline DMU3 & 000925 & UniTTEC & 8.950 & 14.096 & 4.271 & 3.389 & 1.759 & 0.744 & -0.933 & 0.159 \\
\hline DMU4 & 002015 & GCL Energy Technology & 0.557 & 0.363 & 1.370 & 0.660 & 0.000 & 0.073 & -11.268 & 0.180 \\
\hline DMU5 & 002479 & $\begin{array}{l}\text { Fuchunjiang Environmental } \\
\text { Thermoelectric }\end{array}$ & 5.897 & 2.529 & 1.307 & 29.265 & 1.310 & 2.921 & 9.381 & 1.556 \\
\hline DMU6 & 002499 & *ST Kelin & 1.224 & 6.424 & 0.057 & 2.018 & 0.018 & -2.505 & -0.938 & 0.247 \\
\hline DMU7 & 002645 & Huahong Technology & 3.845 & 1.850 & 5.916 & 3.927 & 0.111 & 1.415 & 4.136 & 0.445 \\
\hline DMU8 & 300090 & $\begin{array}{l}\text { Shengyun Environment Pro- } \\
\text { tection Group }\end{array}$ & 8.194 & 11.888 & 9.092 & 6.892 & 5.523 & -22.230 & -14.956 & 1.066 \\
\hline DMU9 & 300165 & Skyray Instrument & 4.946 & 2.935 & 3.680 & 2.035 & 0.070 & 0.825 & 3.292 & 0.563 \\
\hline DMU10 & 300172 & Cec Environmental Protection & 1.157 & 4.343 & 1.882 & 1.185 & 3.741 & 1.248 & 5.576 & 0.632 \\
\hline DMU11 & 300190 & Welle Environmental Group & 10.631 & 9.833 & 11.798 & 4.973 & 2.335 & 1.956 & 5.528 & 0.501 \\
\hline DMU12 & 300203 & Focused Photonics & 10.814 & 17.030 & 12.833 & 4.819 & 0.889 & 5.850 & 18.294 & 1.681 \\
\hline DMU13 & 300262 & Safbon Water Service & 5.139 & 4.046 & 5.916 & 1.596 & 0.196 & 1.224 & 5.675 & 0.495 \\
\hline DMU14 & 300266 & $\begin{array}{l}\text { Xingyuan Environment Tech- } \\
\text { nology }\end{array}$ & 6.209 & 14.155 & 43.119 & 3.890 & 0.138 & -4.554 & 1.297 & 0.414 \\
\hline DMU15 & 300272 & $\begin{array}{l}\text { Canature Health Technology } \\
\text { Group }\end{array}$ & 1.258 & 1.501 & 1.375 & 4.630 & 2.527 & 1.801 & 2.582 & 0.676 \\
\hline DMU16 & 300385 & $\begin{array}{l}\text { Xuelang Environmental Tech- } \\
\text { nology }\end{array}$ & 2.139 & 4.934 & 4.389 & 3.439 & 0.027 & 0.571 & 3.512 & 0.495 \\
\hline DMU17 & 300388 & $\begin{array}{l}\text { Guozhen Environment Pro- } \\
\text { tection Technology }\end{array}$ & 9.317 & 8.623 & 5.824 & 2.233 & 7.376 & 2.593 & 8.093 & 0.618 \\
\hline DMU18 & 300495 & Misho Ecology \& Landscape & 13.978 & 18.192 & 14.752 & 0.736 & 0.028 & 3.354 & 9.547 & 0.610 \\
\hline DMU19 & 600475 & Huaguang Boiler & 16.298 & 25.320 & 14.429 & 19.210 & 4.096 & 4.702 & 36.155 & 2.274 \\
\hline DMU20 & 600481 & $\begin{array}{l}\text { Shuangliang Eco-energy Sys- } \\
\text { tems }\end{array}$ & 12.393 & 7.484 & 4.179 & 4.788 & 0.341 & 1.748 & 1.811 & 3.484 \\
\hline DMU21 & 600502 & $\begin{array}{l}\text { Anhui Construction Engineer- } \\
\text { ing Group }\end{array}$ & 86.058 & 168.370 & 256.454 & 30.805 & 0.536 & 8.007 & 27.037 & 3.924 \\
\hline DMU22 & 600526 & *ST Feida & 9.004 & 12.557 & 24.798 & 9.993 & 2.429 & -3.127 & -1.536 & 0.353 \\
\hline DMU23 & 600649 & Chengtou Holding & 53.396 & 0.502 & 208.799 & 0.198 & 0.000 & 14.683 & 120.883 & 22.518 \\
\hline DMU24 & 601199 & Jiangnan Water & 9.926 & 1.798 & 0.353 & 19.691 & 5.019 & 2.191 & 11.353 & 1.664 \\
\hline DMU25 & 603568 & $\begin{array}{l}\text { Weiming Environment Pro- } \\
\text { tection }\end{array}$ & 8.636 & 3.015 & 0.900 & 1.070 & 7.855 & 6.225 & 15.636 & 1.459 \\
\hline DMU26 & 603822 & Jiaao Enprotech Stock & 2.900 & 0.423 & 2.561 & 2.919 & 1.461 & 0.543 & 3.335 & 0.401 \\
\hline Average & & & 12.689 & 14.123 & 25.538 & 7.657 & 1.926 & 2.203 & 14.360 & 2.040 \\
\hline Maximum & & & 86.058 & 168.370 & 256.454 & 30.805 & 7.855 & 25.568 & 120.883 & 22.518 \\
\hline Minimum & & & 0.557 & 0.363 & 0.057 & 0.198 & 0.000 & -22.230 & -14.956 & 0.159 \\
\hline
\end{tabular}


Table 3: Overall results of capital allocation efficiency of energy conservation and environmental protection enterprises in the Yangtze River delta of China.

\begin{tabular}{|c|c|c|c|c|c|c|c|c|c|}
\hline DMU & $\begin{array}{l}\text { Comprehensive } \\
\text { efficiency }\end{array}$ & $\begin{array}{l}\text { Pure } \\
\text { technical } \\
\text { efficiency }\end{array}$ & $\begin{array}{l}\text { Scale } \\
\text { efficien- } \\
\text { cy }\end{array}$ & $\begin{array}{l}\text { Increase or } \\
\text { decrease of } \\
\text { returns to } \\
\text { scale }\end{array}$ & DMU & $\begin{array}{l}\text { Comprehensive } \\
\text { efficiency }\end{array}$ & $\begin{array}{l}\text { Pure } \\
\text { technical } \\
\text { efficiency }\end{array}$ & $\begin{array}{l}\text { Scale ef- } \\
\text { ficiency }\end{array}$ & $\begin{array}{l}\text { Increase or } \\
\text { decrease of } \\
\text { returns to } \\
\text { scale }\end{array}$ \\
\hline DMU1 & 0.586 & 0.588 & 0.997 & irs & DMU14 & 0.156 & 0.159 & 0.982 & irs \\
\hline DMU2 & 1 & 1 & 1 & - & DMU15 & 1 & 1 & 1 & - \\
\hline DMU3 & 0.157 & 0.170 & 0.922 & irs & DMU16 & 0.821 & 0.892 & 0.921 & irs \\
\hline DMU4 & 1 & 1 & 1 & - & DMU17 & 0.397 & 0.399 & 0.994 & drs \\
\hline DMU5 & 1 & 1 & 1 & - & DMU18 & 1 & 1 & 1 & - \\
\hline DMU6 & 1 & 1 & 1 & - & DMU19 & 0.620 & 0.642 & 0.967 & drs \\
\hline DMU7 & 0.571 & 0.614 & 0.930 & irs & DMU20 & 1 & 1 & 1 & - \\
\hline DMU8 & 0.356 & 0.398 & 0.895 & drs & DMU21 & 0.268 & 0.419 & 0.639 & drs \\
\hline DMU9 & 0.716 & 0.716 & 0.999 & drs & DMU22 & 0.096 & 0.097 & 0.982 & drs \\
\hline DMU10 & 1 & 1 & 1 & - & DMU23 & 1 & 1 & 1 & - \\
\hline DMU11 & 0.281 & 0.290 & 0.967 & irs & DMU24 & 1 & 1 & 1 & - \\
\hline DMU12 & 0.943 & 0.983 & 0.959 & irs & DMU25 & 1 & 1 & 1 & - \\
\hline DMU13 & 0.607 & 0.847 & 0.717 & irs & DMU26 & 0.863 & 1 & 0.863 & irs \\
\hline
\end{tabular}

According to the increase and decrease of returns to scale, 11 DEA-effective sample enterprises show the same returns to scale, nine sample enterprises show the same returns to scale. Hence, $76.923 \%$ of sample enterprises show the same returns to scale. Only six sample enterprises show decreasing returns to scale, accounting for $23.077 \%$ of the total sample enterprises. This result is closely related to the state-issued relevant policies that aim to strengthen environmental protection and encourage the development of environmental protection enterprises. Many energy-saving and environmental protection enterprises, under the incentive of preferential policies, increase capital investment, promote the continuous growth of market scale, and seize market share with the rapid growth of enterprise scale.

Results by industry: Table 4 shows the average values of comprehensive, purely technical, and scale efficiencies of the capital allocation efficiency of enterprises in different industries: power, heat, gas, and water production and supply industry (1), real estate industry (1) > manufacturing industry $(0.671)>$ water conservancy, environment, and public facilities management industry $(0.634)>$ construction industry (0.268). Among the 13 manufacturing enterprises, five enterprises have increasing returns to scale, and three enterprises have unchanged returns to scale. Among the seven

Table 4: Results of capital allocation efficiency of energy conservation and environmental protection enterprises in the Yangtze River Delta of China by Industry.

\begin{tabular}{|lllll|}
\hline Industry & Type & Comprehensive efficiency & Pure technical efficiency & Scale efficiency \\
\hline Manufacturing industry & Average & 0.671 & 0.700 & 0.957 \\
& Minimum & 0.096 & 0.097 & 0.671 \\
Water conservancy, environment and public facil- & Average & 0.634 & 0.159 & 0.951 \\
ities management & Minimum & 0.156 & 1 & 1 \\
Power, heat, gas and water production and supply & Average & 1 & 1 & 1 \\
industry & Minimum & 1 & 1 & 1 \\
Real estate industry & Average & 1 & 1 & 1 \\
& Minimum & 1 & 0.419 & 0.639 \\
Construction industry & Average & 0.268 & 0.419 & 0.639 \\
\hline
\end{tabular}


Table 5: Results of capital allocation efficiency of energy conservation and environmental protection enterprises in the Yangtze River delta of China by region.

\begin{tabular}{|lllll|}
\hline Region & Type & Comprehensive efficiency & Pure technical efficiency & Scale efficiency \\
\hline \multirow{2}{*}{ Jiangsu } & Average & 0.815 & 0.826 & 0.983 \\
& Minimum & 0.281 & 0.290 & 0.921 \\
\multirow{2}{*}{ Zhejiang } & Average & 0.602 & 0.630 & 0.958 \\
& Minimum & 0.096 & 0.097 & 0.863 \\
Shanghai & Average & 0.869 & 0.949 & 0.906 \\
& Minimum & 0.607 & 0.847 & 0.717 \\
Anhui & Average & 0.340 & 0.405 & 0.843 \\
& Minimum & 0.268 & 0.398 & 0.639 \\
\hline
\end{tabular}

water conservancy, environment, and public facility management enterprises, three enterprises show increasing returns to scale, and only one enterprise indicates decreasing returns to scale. The capital allocation efficiency of power, heat, gas, and water production and supply enterprises is DEA-effective, and the returns to scale remain unchanged. Only one real estate enterprise and its capital allocation efficiency is DEA-efficient, and the returns to scale remain unchanged. The number of construction enterprises is 1 , and the returns to scale decrease. Power, heat, gas, and water production and supply enterprises belong to government monopoly enterprises that have strong capital investment and stable market. However, the construction industry has high technical standards, increased requirements, slow technological innovation, and long capital return cycle. The manufacturing industry has many kinds, a large number of enterprises, and a variety of products. Several enterprises actively invest in capital, accelerate the research and development of energy conservation and environmental protection technology, and quickly seize the market. Other enterprises may maintain the status quo or change the original business scope, resulting in overall scale decline.

Results by region: According to Table 5, the average values of comprehensive, purely technical, and scale efficiencies of enterprise capital allocation in different regions are Shanghai (0.869) > Jiangsu (0.815) > Zhejiang (0.602) > Anhui (0.340). Among the 13 enterprises in Zhejiang Province, four enterprises are with increasing returns to scale, seven enterprises with unchanged returns to scale, and only two enterprises are with decreasing returns to scale. Among the seven enterprises in Zhejiang Province, four enterprises have increasing returns to scale, and only one enterprise with decreasing returns to scale. Among the three enterprises in Shanghai, two enterprises are with unchanged returns to scale, and one enterprise with increasing returns to scale. It shows that decreasing returns to scale of the three enterprises in Anhui Province. Shanghai has good location advantages and financial and human resources. It has also issued a series of measures to encourage the development of energy-saving and environmental protection enterprises. However, due to the relatively poor geographical environment, lack of high-level talents, and technological innovation, the overall efficiency of the capital allocation of energy-saving and environmental protection enterprises is low. Jiangsu and Zhejiang Provinces are strong economic provinces and have strong capital, human resources, and technical support. Consequently, the energy-saving and environmental protection enterprises in those provinces have high capital allocation efficiency and show rapid growth.

\section{Improvement Strategy of Capital Allocation Efficiency}

Table 6 shows the many improvements in the input and output variables of non-DEA effective energy conservation and environmental protection enterprises in the Yangtze River Delta. Taking *ST Feida as an example, its capital allocation efficiency projection points on the production front are $(0$, $0,3.591)$ and $(9.004,2.451,24.798,4.169,1.862)$, whereas its initial input and output are $(9.004,12.557,24.798,9.993$, $2.429)$ and $(-3.127,-1.536,0.353)$, respectively. As the negative output is adjusted to 0 in DEA analysis, *ST Feida should adjust its net profit by 3127 million RMB, the undistributed profit of 153.6 million RMB, and surplus reserve of 323.8 million RMB. When DEA is effective, *ST Feida can reduce the accounts receivable of 1.0106 billion RMB, fixed assets of 580.1 million RMB, and construction in progress of 56.7 million RMB. The many accounts receivable and fixed assets in *ST Feida lead to the high capital occupation. Poor performance leads to continuous losses of the enterprise. Thus, launching relevant preferential strategies, recovering accounts receivable, promoting inventory sales, and speeding up the turnover of fixed assets are necessary. For example, the investment of Anhui Construction Engineering Group is $(86.058168 .370256 .454,30.805,0.536)$. The first four inputs are the highest level in the industry, but the 
Table 6: Improvement strategy for capital allocation efficiency of energy conservation and environmental protection enterprises in the Yangtze River Delta of China.

\begin{tabular}{|c|c|c|c|c|c|c|c|c|c|}
\hline \multirow{3}{*}{ DMU } & \multirow{3}{*}{$\begin{array}{l}\text { Comprehen- } \\
\text { sive } \\
\text { efficiency }\end{array}$} & \multicolumn{8}{|c|}{ Improvement strategy } \\
\hline & & \multicolumn{3}{|c|}{ Output variables } & \multicolumn{5}{|c|}{ Input variables } \\
\hline & & $\mathrm{Y}_{1}$ & $\mathrm{Y}_{2}$ & $\mathrm{Y}_{3}$ & $X_{1}$ & $\mathrm{X}_{2}$ & $X_{3}$ & $\mathrm{X}_{4}$ & $\mathrm{X}_{5}$ \\
\hline DMU1 & 0.586 & 2.798 & 9.914 & 2.568 & 8.360 & 4.108 & 9.530 & 8.250 & 0.970 \\
\hline DMU2 & 1 & 25.568 & 104.043 & 5.101 & 28.675 & 19.577 & 14.385 & 26.461 & 1.334 \\
\hline DMU3 & 0.157 & 4.351 & 0 & 1.000 & 6.770 & 5.091 & 4.270 & 3.390 & 1.760 \\
\hline DMU4 & 1 & 0.073 & 0 & 0.180 & 0.557 & 0.363 & 1.370 & 0.660 & 0 \\
\hline DMU5 & 1 & 2.921 & 9.381 & 1.556 & 5.897 & 2.529 & 1.307 & 29.265 & 1.310 \\
\hline DMU6 & 1 & 0 & 0 & 0.247 & 1.224 & 6.424 & 0.057 & 2.018 & 0.018 \\
\hline DMU7 & 0.571 & 2.296 & 10.119 & 0.943 & 3.643 & 1.850 & 5.920 & 2.646 & 0.110 \\
\hline DMU8 & 0.356 & 0 & 0 & 2.691 & 8.190 & 4.332 & 9.090 & 4.570 & 1.404 \\
\hline DMU9 & 0.716 & 1.145 & 4.677 & 0.782 & 2.884 & 2.584 & 3.680 & 2.030 & 0.070 \\
\hline DMU10 & 1 & 1.248 & 5.576 & 0.632 & 1.157 & 4.343 & 1.882 & 1.185 & 3.741 \\
\hline DMU11 & 0.281 & 6.750 & 26.295 & 2.119 & 10.630 & 6.276 & 11.800 & 4.970 & 2.340 \\
\hline DMU12 & 0.943 & 5.951 & 23.893 & 1.819 & 10.810 & 8.419 & 12.830 & 4.820 & 0.890 \\
\hline DMU13 & 0.607 & 1.773 & 6.692 & 0.654 & 4.418 & 4.050 & 5.920 & 1.600 & 0.200 \\
\hline DMU14 & 0.156 & 0 & 12.979 & 2.580 & 6.210 & 0.438 & 23.398 & 0.831 & 0.140 \\
\hline DMU15 & 1 & 1.801 & 2.582 & 0.676 & 1.258 & 1.501 & 1.375 & 4.630 & 2.527 \\
\hline DMU16 & 0.821 & 0.837 & 3.936 & 0.585 & 1.889 & 0.795 & 4.390 & 1.236 & 0.030 \\
\hline DMU17 & 0.397 & 6.522 & 20.264 & 1.922 & 9.320 & 3.918 & 5.820 & 2.230 & 6.782 \\
\hline DMU18 & 1 & 3.354 & 9.547 & 0.610 & 13.978 & 18.192 & 14.752 & 0.736 & 0.028 \\
\hline DMU19 & 0.62 & 13.351 & 56.325 & 3.537 & 16.300 & 11.614 & 14.430 & 13.373 & 2.376 \\
\hline DMU20 & 1 & 1.748 & 1.811 & 3.484 & 12.393 & 7.484 & 4.179 & 4.788 & 0.341 \\
\hline DMU21 & 0.268 & 19.102 & 114.043 & 15.447 & 43.363 & 8.247 & 129.867 & 10.862 & 0.536 \\
\hline DMU22 & 0.096 & 0 & 0 & 3.591 & 9.004 & 2.451 & 24.798 & 4.169 & 1.862 \\
\hline DMU23 & 1 & 14.683 & 120.883 & 22.518 & 53.396 & 0.502 & 208.799 & 0.198 & 0.000 \\
\hline DMU24 & 1 & 2.191 & 11.353 & 1.664 & 9.926 & 1.798 & 0.353 & 19.691 & 5.019 \\
\hline DMU25 & 1 & 6.225 & 15.636 & 1.459 & 8.636 & 3.015 & 0.900 & 1.070 & 7.855 \\
\hline DMU26 & 0.863 & 0.543 & 3.335 & 0.401 & 2.900 & 0.423 & 2.561 & 2.919 & 1.461 \\
\hline
\end{tabular}

output is not high. According to the improvement strategy, the projection point of capital allocation efficiency on the production front is $(19.102,114.043,15.447)$ and $(43.363$, $8.247129 .867,10.862,0.536)$. The comprehensive efficiency of the salary cost allocation of Anhui construction is only 0.268 , and the scale efficiency is the lowest $(0.639)$ of the sample enterprises. These figures show that the returns on the scale are decreasing, that is, enterprises do not give full play to the scale effect, as many investments cause great waste and consume most of the profits. Therefore, enterprises should increase output and adjust net profit of 1.109 billion yuan, the undistributed profit of 9.106 billion yuan, and surplus reserve of 1.152 billion yuan. In addition, enterprises should consider reducing diversified operation, centralizing advantages, and improving profit point. Besides, according to the results of Jiaao Enprotech Stock, although pure technical efficiency reaches 1 , its scale efficiency is insufficient at only 0.863 , which increases the scale reward. Hence, its scale must be expanded, and its scale advantage should be given full play.

\section{CONCLUSION}

Through the analysis of the capital allocation efficiency of energy-saving and environmental protection enterprises in the Yangtze River Delta of China, this study mainly draws the following conclusions. First, the comprehensive efficiency of 
the capital allocation of energy-saving and environmental protection enterprises is high at an average value of 0.709 . The scale efficiency is 0.951 . Overall, $42.308 \%$ of sample enterprises realize DEA efficiency, which shows that the capital utilization efficiency and income of energy-saving and environmental protection enterprises are good. Second, the comprehensive efficiency of the capital allocation of energy-saving and environmental protection enterprises is different, as the highest is 1 , and the minimum is 0.096 . Hence, huge differences are observed at the development level and in the strength among enterprises, and the market competition is intense. Third, differences are found in the average value of comprehensive efficiency among different industries, including power, heat, gas, and water production and supply industry (1), real estate industry (1), manufacturing industry (0.671), water conservancy, environment and public facilities management industry (0.634), and construction industry (0.268); Fourth, differences are observed in comprehensive efficiency among different regions, such as Shanghai (0.869), Jiangsu (0.815), Zhejiang (0.602), and Anhui (0.340). Fifth, more than two-thirds of the sample enterprises show constant or increasing scale. Hence, capital is not only in the stage of increasing in energy-saving and environmental protection enterprises but also forms scale effect, realizes effective integration of resources, and improves comprehensive income. Sixth, from the perspective of monetary capital, accounts receivable, and fixed assets, the average values are 1268.9, 1413.3, and 765.7 million RMB, respectively. The fixed assets are at a low level, whereas accounts receivable are too many. Hence, attention should be paid to prevent the risk of bad debts of accounts receivable. In addition, the average value of inventory is 2553.8 million RMB, which is at a high level. Hence, a necessary program is to speed up inventory turnover and prevent inventory depreciation.

\section{ACKNOWLEDGEMENT}

The study was supported by Grant from the Development Center of Shanghai Municipal People's Government (2019U-A02).

\section{REFERENCES}

Bravo-Macias, C., Sarmentero-Bon, I., Rodriguez-Sanchez, Y. and GomezFigueroa, O. 2019. Evaluation of organizational competencies through performance indicators. DYNA, 94(5): 490.

Hao, W.B., Li, S.G., Lei, Y.X., Song, Z.J. and Dong, J.C. 2018. Study on efficiency evaluation of energy conservation and environmental protection industry in China. Science and Technology for Development, 14(4): 223-231.

Peng, H., He, Z.C., Wu, Y. and Deng, Y. 2017. Research on composition and cultivation of modern energy conservation and environmental protection industry. Mining Research and Development, 37(3): 112-120.

Sun, Y. 2018. Development status and policy recommendations of energy conservation and environmental protection industry. China Energy, 40(12): 23-24.

Wang, Z.K. 2017. Definition and scope of energy conservation and environmental protection industry. China Strategic Emerging Industry, (12): 45-46.

Xiong, Z., Wang, P.J. and Zhao, Y. 2020. Re-innovation from failure, institutional environmental differences, and firm performance: Evidence from China. Amfiteatru Economic, 22(53): 197-219.

Xiong, Z.D. and Lin, X. 2010. Financial support efficiency of listed companies in energy conservation and environmental protection industry and its influencing factors. Economic Management, (11): 26-33.

Xu, F.J. and Dai, F. 2017. Capital allocation efficiency evaluation of household appliance enterprises based on DEA model. Journal of Finance and Accounting, (8), 44-48.

Yan, J.Z. and Qi, N.N. 2019. Research on performance evaluation of China's strategic emerging industries - taking energy conservation and environmental protection industries as an example. Journal of Henan University of Engineering (Social Science Edition), 34(1): 13-18.

Yu, Y.B., Du, Y.C. and Gao, Y. 2016. Evaluation of the operation efficiency of listed companies in LED lighting industry of China based on DEA model. Light \& Engineering, 24(3): 161-165. 